\title{
Penetapan Kadar Flavonoid Total Pada Beberapa Bagian Tanaman Kepel (Stelecocharpus burahol Hook F. \& Th)
}

\author{
Elfasyari, T.Y. ${ }^{*}$, H. Marliza ${ }^{1}$ \\ ${ }^{1}$ Program Studi Sarjana Farmasi, STIKes Mitra Bunda Persada, \\ Jl. Seraya, Batam, Indonesia, 29444 \\ *Corresponding author e-mail: trieelfasyari@gmail.com
}

Riwayat artikel: Dikirim: 02-10-2019; Diterima: 20-01-2020, Diterbitkan: 21-01-2020

\begin{abstract}
ABSTRAK
Kepel merupakan tanaman asli Indonesia yang biasa dijumpai di daerah-daerah Keraton di pulau Jawa. Kepel memiliki filosofi tersendiri bagi keraton, disamping buahnya bermanfaat untuk memelihara kecantikan puteri-puteri Keraton, daunnya juga berkhasiat menurunkan kolesterol. Khasiat tersebut dikarenakan kepel mengandung zat aktif seperti flavonoid, saponin, tanin, alkaloid, dan steroid. Belum ada data yang mendetail mengenai kadar flavonoid total pada ekstrak etanol beberapa bagian tanaman kepel. Pada penelitian ini kadar flavonoid total yang akan ditetapkan yaitu pada bagian daun yang masih muda, daun yang tua, dan biji. Bagian tanaman kepel di ekstraksi menggunakan metode sokletasi dengan etanol 96\% sebagai pelarut. Uji pendahuluan dilakukan dengan menggunakan fase diam plate selulosa dan fase gerak n-butanol-asam asetat-akuades (4:5:1). Kadar flavonoid total ditetapkan dengan metode spektrofotometri visibel menggunakan aluminium klorida sebagai reaksi pembentuk komplek. Hasil ANOVA menunjukkan bahwa kadar flavonoid total dalam ekstrak etanol daun yang masih muda, daun yang tua dan biji berturut-turut adalah $(3,32 \pm 0,12) ;(4,82 \pm 0,08)$, dan $(0,25 \pm 0,01) \% \mathrm{~b} / \mathrm{b}$. Dari hasil analisis tersebut dapat disimpulkan kadar flavonoid total berbeda bermakna pada ekstrak etanol tiga bagian tanaman kepel dan flavonoid total yang paling banyak terdapat pada ekstrak etanol daun yang tua.
\end{abstract}

Kata kunci: kepel, Stelecocarpus burahol Hook F. \& Th, Flavonoid total, Spektrofotometri visibel.

\section{ABSTRACT}

Kepel, Stelecocharpus burabol Hook F. \& Th are originally grows in Indonesia. This plant is usually found in the Palace at Java island. Kepel has its own phylosophical meaning for the Palace, and the fruit is useful to maintain the beauty of princes of the Palace, the leaves are also nutritious to decrease cholesterol level. Efficacy of kepel is due to its contain active substance suchs us flavonoids, saponins, tannins, alkaloids, and steroids. There are currently no detailed data about levels of flavonoids in S. burahol. It is needs to be researched for determination of total flavonoid content ethanolic extract in different parts (young leaves, old leaves and seeds ) of $S$. burahol. Each part of plant were extracted by soxhlet using $96 \%$ ethanol as the solvent. Preliminary tests was conducted using cellulose plates as stationary phase and the mobile phase of n-butanol-acetic acid-aquadest (4:1:5, upper phase). Total flavonoid content was determined by visible spectrophotometric using alluminium chloride as chelating agent. The result of ANOVA analysis obtained showed that the total flavonoid content in ethanolic extracts leaves (young and old) and seeds, respectively (3.32 \pm 0.12$) ;(4.82 \pm 0.08)$, and $(0.25 \pm 0.01) \%$. The $96 \%$ ethanol of old leaves extract of S. burahol showed the highest of total flavonoid content as $4.82 \pm 0.08 \%$.

Keywords: Kepel, Stelecocarpus burabol Hook F. \& Th, Total Flavonoid Content, Visible spectrophotometry

\section{PENDAHULUAN}

Masyarakat Indonesia mengenal dan memakai tanaman berkhasiat obat sebagai salah satu upaya dalam penanggulangan masalah kesehatan, jauh sebelum pelayanan kesehatan formal dengan obat-obat modern menyentuh masyarakat (Dalimartha, 1992). Salah satu tanaman berkhasiat obat yang digunakan adalah
Kepel (Stelecocharpus burahol Hook F.\& Th). Kepel termasuk tanaman yang lanka di Indonesia. Tanaman ini biasa dijumpai di daerah keratonkeraton di Pulau Jawa. Pohon Kepel mempunyai arti filosofis tersendiri bagi keraton, disamping buahnya berguna untuk memelihara kecantikan puteri-puteri keraton, daunnya juga berkhasiat untuk menurunkan kolesterol (Siswono, 2002). 


\section{Elfasyari dan Marliza}

DOI : https://doi.org/10.24843/JFU.2019.v08.i02.p08

pISSN: 2301-7716; eISSN: 2622-4607

Jurnal Farmasi Udayana, Vol 8, No 2, Tahun 2019, 110-115

Penelitian terdahulu menunjukkan bahwa pemberian infusa daun kepel dapat menurunkan kadar asam urat darah pada tikus dan pada ayam. Fraksi larut dan tidak larut petroleum eter daun kepel dapat menyebabkan penurunan kadar asam urat darah ayam hiperurisemia (Sutomo, 2013). Selain itu, telah dilakukan penelitian yang relevan tentang aktivitas flavonoid antioksidan penangkap radikal bebas dari daun kepel yang menghasilkan 5 isolat dari daun kepel. Semua isolat penangkap radikal dan hasil identifikasinya menunjkkan 3,7,3',4'-tetrahidroksi-5-metil flavon merupakan isolat paling aktif dengan EC50 6,34 $\mu \mathrm{g} / \mathrm{mL}$ (Sunarni, 2007).

Flavonoid terdapat pada hampir seluruh bagian tanaman kepel. Penapisan fitokimia terhadap simplisia daging buah kepel menunjukkan adanya senyawa golongan alkaloid, polifenol, flavonoid, dan saponin (Rinawati, 2004). Tanaman kepel mengandung flavonoid, saponin, tannin, alkaloid, dan steroid. Flavonoid merupakan senyawa fenol, yang bermanfaat sebagai antioksidan, aktivitas anti kanker, anti alergi, anti virus, dan anti inflamasi (Anonim, 2009).

Mengingat banyaknya manfaat flavonoid bagi kehidupan manusia, maka penelitian mengenai kadar flavonoid total yang terkandung dalam biji buah kepel perlu dilakukan. Dengan demikian, pemanfaatan tanaman kepel lebih optimal dan lebih terarah kepada bagian tanaman kepel yang paling baik untuk digunakan.

\section{BAHAN DAN METODE} Alat dan Bahan

Alat yang digunakan pada penelitian ini adalah spektrofotometer (Pharmaspec UV 1700, Shimadzu), alat shoxlet, kertas saring, rotary evaporator, cawan porselin, bejana kromatografi, timbangan analitik, alat-alat gelas, mikropipet, plate selulosa, pipa kapiler 5 mikroliter, alat penyemprot dan blender.

Bahan yang digunakan antara lain daun muda, daun tua, dan biji buah tanaman kepel, etanol 96\% (kualitas pro analisis), kuersetin (kualitas pro analisis), petroleum eter (kualitas teknis), $\mathrm{AlCl}_{3} \cdot 6 \mathrm{H}_{2} \mathrm{O}$ (E-Merck), amoniak, asam sitrat, asam borat, metanol, n-butanol, asam asetat dan akuades.

\section{Metode \\ Pembuatan Ekstrak Etanol}

Ekstrak etanol dibuat dengan alat Soxblet. Sebanyak 30 gram serbuk bagian tanaman kepel dibungkus dengan kertas saring, dimasukkan dalam alat soxhlet. Lakukan pengawalemakkan dengan PE, kemudian disari menggunakan etanol $96 \%$ sampai cairan yang mengalir dari rumah siput tidak berwarna lagi. Sari etanol yang diperoleh dipekatkan dengan rotary evaporator.

\section{Uji Kualitatif Flavonoid}

Ekstrak etanol ditotolkan pada fase diam plate selulosa menggunakan pipa kapiler hingga totolan jelas terlihat secara visual. Plate selulosa kemudian dikembangkan dalam fase gerak nbutanol:asam asetat:air (4:1:5) fase atas, hingga batas elusi. Kromatogram setelah kering diberi uap amoiak, disemprot dengan pereaksi sitroborat, dan $\mathrm{AlCl}_{3}$.

\section{Penetapan Kadar Flavonoid Total}

Sebanyak $10 \mathrm{mg}$ ekstrak daun kepel yang masih muda dilarutkan dalam $10 \mathrm{ml}$ etanol 96\% p.a, kemudian diambil $1 \mathrm{ml}$ ditambah dengan $1 \mathrm{ml}$ larutan $\mathrm{AlCl}_{3} 2 \%$. Setelah dicampur dengan baik, larutan didiamkan hingga OT (Operating time) dan uji absorbansinya pada panjang gelombang maksimum, sehingga diperoleh konsentrasi flavonoid total. Jika absorbansi terlalu bear, pengujian sampel diulangi dengan melakukan pengenceran. Perlakuan yang sama dikerjakan terhadap ekstrak daun kepel yang tua dan ekstrak biji buah kepel.

\section{Analisis Data}

Analisis data terlebih dahulu dilakukan dengan metode kurva standar regresi linier $\mathrm{y}=\mathrm{bx}$ + a dibuat berdasarkan data luas area di bawah kurva dan konsentrasi dari larutan standar. Untuk mengambil kesimpulan digunakan parameter ketetapan dan ketelitian. Besar kecilnya kesalahan diketahui dengan standar error (SE). Analisis data dilanjutkan dengan menguji normalitas dan homogenitas dengan taraf kepercayaan 95\%. Uji normalitas dilakukan dengan Kolmogorov-Smirnov untuk mengetahui data terdistribusi normal atau tidak. Uji homogenitas dilakukan dengan uji Levene untuk mengetahui varian data homogen atau tidak. Apabila hasil uji normalitas dan homogenitas menunjukkan bahwa data terdistribusi normal dan homogen, maka analisa dilanjutkan dengan metoda parametrik ANOVA 


\section{Elfasyari dan Marliza}

DOI : https://doi.org/10.24843/JFU.2019.v08.i02.p08

pISSN: 2301-7716; eISSN: 2622-4607

Jurnal Farmasi Udayana, Vol 8, No 2, Tahun 2019, 110-115

dan uji Post Hoc. Apabila hasil uji menunjukkan bahwa data tidak terdistribusi normal dan tidak homogen atau salah satu dari keduanya, uji dilanjutkan dengan metode non parametrik, yakni uji Kruskal-Wallis dan dilanjutkan dengan MannWhitney. Data dikatakan terdistribusi normal dan homogen apabila masing-masing hasil uji mempunyai nilai signifikansi lebih 0,05.

\section{HASIL}

Hasil identifikasi selengkapnya dapat dilihat pada Tabel 1, Tabel 2., dan Tabel 3. Hasil penetapan kadar flavonoid total dari ekstrak etanol beberapa bagian tanaman kepel dapat dilihat pada Tabel 4.

Tabel 1. Data kromatogram uji kualitatif flavonoid dengan uap amoniak

\begin{tabular}{|c|c|c|c|c|c|c|c|c|}
\hline \multirow[b]{2}{*}{ Sampel } & \multirow[b]{2}{*}{$\mathbf{R} f$} & \multicolumn{3}{|c|}{ Sebelum perlakuan } & \multicolumn{3}{|c|}{ Setelah perlakuan } & \multirow{2}{*}{$\begin{array}{c}\text { Penafsiran } \\
\text { jenis } \\
\text { flavonoid }\end{array}$} \\
\hline & & Vis & UV254 & UV366 & Vis & UV254 & UV366 & \\
\hline Kuersetin & 0,71 & $\begin{array}{c}\text { Kuning } \\
\text { pucat }\end{array}$ & $\begin{array}{c}\text { Kuning } \\
\text { terang }\end{array}$ & Kuning & Kuning & $\begin{array}{c}\text { Kuning } \\
\text { terang }\end{array}$ & Kuning & \\
\hline Daun muda & $\begin{array}{l}0,59 \\
0,29\end{array}$ & $\begin{array}{l}\text { Kuning } \\
\text { pucat }\end{array}$ & $\begin{array}{c}\text { Hijau } \\
\text { kekuningan }\end{array}$ & $\begin{array}{c}\text { Biru } \\
\text { kehijauan } \\
\text { Biru } \\
\text { terang }\end{array}$ & $\begin{array}{l}\text { Kuning } \\
\text { pucat }\end{array}$ & $\begin{array}{c}\text { Biru } \\
\text { kehijauan }\end{array}$ & $\begin{array}{l}\text { Kuning } \\
\text { kehijauan }\end{array}$ & $\begin{array}{c}\text { Flavonol yang } \\
\text { mengandung } \\
\text { 3-OH bebas } \\
\text { dan tanpa 5- } \\
\text { OH bebas }\end{array}$ \\
\hline Daun tua & $\begin{array}{l}0,60 \\
0,33\end{array}$ & $\begin{array}{c}\text { Kuning } \\
\text { pucat }\end{array}$ & $\begin{array}{c}\text { Hijau } \\
\text { kekuningan }\end{array}$ & $\begin{array}{c}\text { Biru } \\
\text { kehijauan } \\
\text { Biru } \\
\text { terang }\end{array}$ & $\begin{array}{c}\text { Kuning } \\
\text { pucat }\end{array}$ & $\begin{array}{c}\text { Biru } \\
\text { kehijauan }\end{array}$ & $\begin{array}{c}\text { Kuning } \\
\text { kehijauan }\end{array}$ & $\begin{array}{c}\text { Flavonol yang } \\
\text { mengandung } \\
\text { 3-OH bebas } \\
\text { dan tanpa 5- } \\
\text { OH bebas }\end{array}$ \\
\hline Biji & 0,31 & $\begin{array}{c}\text { Tak } \\
\text { tampak }\end{array}$ & $\begin{array}{c}\text { Tak } \\
\text { tampak }\end{array}$ & $\begin{array}{c}\text { Fluresensi } \\
\text { biru } \\
\text { muda }\end{array}$ & $\begin{array}{c}\text { Tak } \\
\text { tampak }\end{array}$ & $\begin{array}{c}\text { Tak } \\
\text { tampak }\end{array}$ & $\begin{array}{c}\text { Fluresensi } \\
\text { biru } \\
\text { muda }\end{array}$ & $\begin{array}{c}\text { Isoflavon yang } \\
\text { tak } \\
\text { mengandung } \\
\text { 5-OH bebas }\end{array}$ \\
\hline
\end{tabular}

Tabel 2. Data kromatogram uji kualitatif flavonoid dengan $\mathrm{AlCl}_{3}$.

\begin{tabular}{|c|c|c|c|c|c|c|c|c|}
\hline \multirow{2}{*}{ Sampel } & \multirow{2}{*}{$\mathbf{R} f$} & \multicolumn{3}{|c|}{ Sebelum perlakuan } & \multicolumn{3}{|c|}{ Setelah perlakuan } & \multirow{2}{*}{$\begin{array}{c}\text { Penafsiran } \\
\text { jenis } \\
\text { flavonoid }\end{array}$} \\
\hline & & Vis & UV254 & UV366 & Vis & UV254 & UV366 & \\
\hline Kuersetin & 0,71 & $\begin{array}{c}\text { Kuning } \\
\text { pucat }\end{array}$ & $\begin{array}{l}\text { Kuning } \\
\text { terang }\end{array}$ & Kuning & Kuning & $\begin{array}{c}\text { Kuning } \\
\text { terang }\end{array}$ & Kuning & \\
\hline Daun muda & $\begin{array}{l}0,59 \\
0,29\end{array}$ & $\begin{array}{c}\text { Kuning } \\
\text { pucat }\end{array}$ & $\begin{array}{c}\text { Hijau } \\
\text { kekuningan }\end{array}$ & $\begin{array}{c}\text { Biru } \\
\text { kehijauan } \\
\text { Biru } \\
\text { terang }\end{array}$ & $\begin{array}{c}\text { Kuning } \\
\text { pucat }\end{array}$ & $\begin{array}{c}\text { Biru } \\
\text { kehijauan }\end{array}$ & $\begin{array}{l}\text { Kuning } \\
\text { kehijauan } \\
\text { Biru } \\
\text { terang }\end{array}$ & $\begin{array}{c}\text { Flavonol yang } \\
\text { mengandung } \\
\text { 3-OH bebas } \\
\text { dan tanpa 5- } \\
\text { OH bebas }\end{array}$ \\
\hline Daun tua & $\begin{array}{l}0,60 \\
0,33\end{array}$ & $\begin{array}{c}\text { Kuning } \\
\text { pucat }\end{array}$ & $\begin{array}{c}\text { Hijau } \\
\text { kekuningan }\end{array}$ & $\begin{array}{c}\text { Biru } \\
\text { kehijauan } \\
\text { Biru } \\
\text { terang }\end{array}$ & $\begin{array}{c}\text { Kuning } \\
\text { pucat }\end{array}$ & $\begin{array}{c}\text { Biru } \\
\text { kehijauan }\end{array}$ & $\begin{array}{l}\text { Kuning } \\
\text { kehijauan } \\
\text { Biru } \\
\text { terang }\end{array}$ & $\begin{array}{c}\text { Flavonol yang } \\
\text { mengandung } \\
\text { 3-OH bebas } \\
\text { dan tanpa 5- } \\
\text { OH bebas }\end{array}$ \\
\hline Biji & 0,31 & $\begin{array}{c}\text { Tak } \\
\text { tampak }\end{array}$ & Tak tampak & $\begin{array}{c}\text { Fluresensi } \\
\text { biru } \\
\text { muda }\end{array}$ & $\begin{array}{c}\text { Tak } \\
\text { tampak }\end{array}$ & $\begin{array}{c}\text { Tak } \\
\text { tampak }\end{array}$ & $\begin{array}{c}\text { Fluresensi } \\
\text { biru } \\
\text { muda }\end{array}$ & $\begin{array}{c}\text { Isoflavon yang } \\
\text { tak } \\
\text { mengandung } \\
\text { 5-OH bebas }\end{array}$ \\
\hline
\end{tabular}


Tabel 3. Data kromatogram uji kualitatif flavonoid dengan sitroborat.

\begin{tabular}{|c|c|c|c|c|c|c|c|c|}
\hline \multirow{2}{*}{ Sampel } & \multirow{2}{*}{$\mathbf{R} f$} & \multicolumn{3}{|c|}{ Sebelum perlakuan } & \multicolumn{3}{|c|}{ Setelah perlakuan } & \multirow{2}{*}{$\begin{array}{c}\text { Penafsiran } \\
\text { jenis } \\
\text { flavonoid }\end{array}$} \\
\hline & & Vis & UV254 & UV366 & Vis & UV254 & UV366 & \\
\hline Kuersetin & 0,71 & $\begin{array}{c}\text { Kuning } \\
\text { pucat }\end{array}$ & $\begin{array}{l}\text { Kuning } \\
\text { terang }\end{array}$ & Kuning & Kuning & $\begin{array}{l}\text { Kuning } \\
\text { terang }\end{array}$ & Kuning & \\
\hline Daun muda & $\begin{array}{l}0,59 \\
0,29\end{array}$ & $\begin{array}{c}\text { Kuning } \\
\text { pucat }\end{array}$ & $\begin{array}{c}\text { Hijau } \\
\text { kekuningan }\end{array}$ & $\begin{array}{c}\text { Biru } \\
\text { kehijauan } \\
\text { Biru } \\
\text { terang }\end{array}$ & $\begin{array}{c}\text { Kuning } \\
\text { pucat }\end{array}$ & $\begin{array}{c}\text { Biru } \\
\text { kehijauan }\end{array}$ & $\begin{array}{c}\text { Kuning } \\
\text { kehijauan } \\
\text { Biru }\end{array}$ & $\begin{array}{c}\text { Flavonol yang } \\
\text { mengandung } \\
\text { 3-OH bebas } \\
\text { dan tanpa 5- } \\
\text { OH bebas }\end{array}$ \\
\hline Daun tua & $\begin{array}{l}0,60 \\
0,33\end{array}$ & $\begin{array}{l}\text { Kuning } \\
\text { pucat }\end{array}$ & $\begin{array}{c}\text { Hijau } \\
\text { kekuningan }\end{array}$ & $\begin{array}{c}\text { Biru } \\
\text { kehijauan } \\
\text { Biru } \\
\text { terang }\end{array}$ & $\begin{array}{l}\text { Kuning } \\
\text { pucat }\end{array}$ & $\begin{array}{c}\text { Biru } \\
\text { kehijauan }\end{array}$ & $\begin{array}{c}\text { Kuning } \\
\text { kehijauan } \\
\text { Biru }\end{array}$ & $\begin{array}{c}\text { Flavonol yang } \\
\text { mengandung } \\
\text { 3-OH bebas } \\
\text { dan tanpa 5- } \\
\text { OH bebas }\end{array}$ \\
\hline Biji & 0,31 & $\begin{array}{c}\text { Tak } \\
\text { tampak }\end{array}$ & Tak tampak & $\begin{array}{c}\text { Fluresensi } \\
\text { biru } \\
\text { muda }\end{array}$ & $\begin{array}{c}\text { Tak } \\
\text { tampak }\end{array}$ & $\begin{array}{l}\text { Tak } \\
\text { tampak }\end{array}$ & $\begin{array}{c}\text { Fluresensi } \\
\text { biru } \\
\text { muda }\end{array}$ & $\begin{array}{c}\text { Isoflavon yang } \\
\text { tak } \\
\text { mengandung } \\
\text { 5-OH bebas }\end{array}$ \\
\hline
\end{tabular}

Tabel 4. Kadar flavonoid total pada ekstrak beberapa bagian tanaman kepel

\begin{tabular}{|c|c|c|c|c|}
\hline Sampel & Replikasi & Absorbansi & $\begin{array}{c}\text { Kadar Flavonoid } \\
\text { Total }(\% \mathrm{~b} / \mathrm{b})\end{array}$ & $\mathrm{X} \pm \mathrm{SD}$ \\
\hline Ekstrak daun & 1 & 0,453 & 3,34 & $3,32 \pm 0,12$ \\
\hline \multirow[t]{4}{*}{ kepel yang muda } & 2 & 0,434 & 3,27 & \\
\hline & 3 & 0,441 & 3,25 & \\
\hline & 4 & 0,427 & 3,22 & \\
\hline & 5 & 0,470 & 3,53 & \\
\hline Ekstrak daun & 1 & 0,321 & 4,83 & $4,82 \pm 0,08$ \\
\hline \multirow[t]{4}{*}{ kepel yang tua } & 2 & 0,304 & 4,72 & \\
\hline & 3 & 0,329 & 4,94 & \\
\hline & 4 & 0,313 & 4,81 & \\
\hline & 5 & 0,316 & 4,81 & \\
\hline Ekstrak biji buah & 1 & 0,320 & 0,25 & $0,25 \pm 0,01$ \\
\hline \multirow[t]{4}{*}{ kepel } & 2 & 0,308 & 0,24 & \\
\hline & 3 & 0,323 & 0,25 & \\
\hline & 4 & 0,315 & 0,24 & \\
\hline & 5 & 0,338 & 0,26 & \\
\hline
\end{tabular}

\section{PEMBAHASAN}

Metode penyarian yang digunakan adalah dengan alat Soxblet. Penyarian dengan alat Soxblet dimaksudkan untuk menyari zat aktif tanaman yang larut dalam pelarut organik dengan menggunakan pelarut sedikit. penyarian dilakukan sampai cairan tidak berwarna lagi, artinya bahwa zat aktif dalam simplisia benar-benar tersari dengan baik.

Pelarut etanol 96\% dipilih sebagai penyari karena etanol mempunyai beberapa keuntungan seperti lebih tepat, sulit ditumbuhi kapang dan mikroba, tidak beracun, netral, dan panas yang diperlukan untuk pemekatan lebih sedikit (Anonim, 1986). Sebelum penyarian dilakukan pengawalemakan dengan petroleum eter untuk menghilangkan zat-zat yang sangat non-polar seperti klorofil dan minyak yang terapat pada simplisia yang dapat mengganggu proses penyarian, karena terjadinya penjenuhan sehingga zat aktif flavonoid hanya sedikit yang tersari. Hasil penyarian dengan alat Soxblet masih perlu 
dipekatkan lagi dengan cara penguapan cairan pelarutnya agar diperoleh ekstrak yang lebih pekat serta tahan lama.

Uji kualitatif dilakukan untuk memastikan adanya kandungan flavonoid dalam biji buah kepel. Untuk itu, ekstrak etanol diteteskan pada kertas saring, setelah kering kemudian diuapi amoniak. Terbentuknya warna kuning menunjukkan adanya senyawa flavonoid. Warna kuning tersebut disebabkan oleh terbentuknya struktur kuinoid. Pada penelitian ini, tetesan kering ekstrak pada kertas saring berwarna kuning dengan uap amoniak.

Selanjutnya, kandungan flavonoid diuji dengan metode kromatografi lapis tipis menggunakan fase gerak n-butanol: asam asetat: air dengan perbandingan 4:1:5 fase atas. Sebagai fase diam digunakan plate selulosa, digunakan plate selulosa karena hasil pemisahannya dengan menggunakan fase gerak tersebut, lebih bagus dibanding dengan menggunakan silika gel GF 254. Hal ini disebabkan terbentuknya khelat oleh logam yang berikatan dengan gugus orthohidroksi karbonil.

Berdasarkan data-data dari tabel diketahui bahwa nilai $\mathrm{R} f$ yang dari semua bercak berbeda dengan pembanding kuersetin. Dilihat dari fase gerak yang relatif non polar, menunjukkan bahwa ketiga sampel tersebut diduga mengandung suatu glikosida flavonoid. Warna biru kehijauan yang diberikan ekstrak daun yang masih muda dan daun yang tua di bawah sinar UV366 dan menjadi kuning kehijauan setelah diberi uap amoniak menunjukkan bahwa kemungkinan adanya flavonol yang mengandung 3-OH bebas dan tanpa $5-\mathrm{OH}$ bebas. Perubahan warna tersebut dikarenakan adanya reaksi antara flavonoid dengan amoniak membentuk struktur kuinoid yang berwarna kuning. Bercak yang diberikan ekstrak biji buah kepel berwarna fluoresensi biru muda di bawah sinar UV366 dan setelah diberi uap amoniak mengalami sedikit perubahan warna menunjukkan kemungkinan adanya suatu isoflavon tanpa 5-OH bebas (Markham, 1988). Dari uraian tersebut dapat disimpulkan bahwa daun kepel yang masih muda dan yang tua mengandung flavonoid jenis flavonol yang mengandung 3-OH bebas dan tanpa 5-OH bebas. Hal ini sesuai dengan hasil yang telah dilakukan sebelumnya yang menyatakan bahwa daun kepel mengandung 3,7,3',4'-tetrahidroksi-5-metilflavon (Sunarni 2007).

Pada penelitian ini kadar flavonoid total dalam ekstrak ditetapkan dengan mengacu penelitian yang dilakukan oleh Soobrattee (2006), yaitu sampel sebanyak 1,0 $\mathrm{ml}$ ditambah dengan 1,0 ml $\mathrm{AlCl}_{3}$. Larutan yang dihasilkan berwarna kuning disebabkan terjadinya reaksi pembentukan kompleks antara aluminium klorida dengan flavonoid.

Flavonoid termasuk golongan fenol yang pada tingkat seluler flavonoid terlokasi pada cairan vakuola (sitoplasma) atau pada dinding sel, kloroplas. Flavonoid biasa dijumpai pada bagian daun, akar, kayu, kulit, tepung sari, bunga dan biji.

Sebagian besar tumbuhan membentuk pigmen disalah satu antosianin dan flavonoid lainnya dalam beberapa sel terspesialisasi di salah satu atau beberapa organnya, dan proses ini sering terpacu oleh cahaya. Produksi Flavonoid memerlukan gula sebagai sumber fosfoenolpiruvat dan eritrosa-4-fosfat yang menyediakan beberapa atom karbon yang diperlukan bagi cincin-B flavonoid, serta sebagai sumber unit asetat untuk cincin-A flavonoid. Gula, khususnya sukrosa, dapat diperoleh dari proses peruraian pati atau lemak di organ penyimpanan saat perkembangan kecambah, atau dari fotosintesis di sel yang mengandung klorofil (Salisbury dan Ross, 1992). Oleh sebab itu dapat dikatakan bahwa sintesis flavonoid dapat ditingkatkan oleh adanya cahaya.

Penimbunan flavonoid di daun saat menua pada musim gugur menunjukkan adanya hubungan antara hidrolisis protein, munculnya fenilalanin dan penggunaan fenilalanin pada pembentukan cincin-B. Karena fenilalanin dapat digunakan pada berbagai lintasan metabolic, diduga cahaya mengendalikan langkah pertama perubahannya menjadi cincin-B. langkah ini memerlukan enzim fenilalanin amino liase dan cahaya yang mendorong aktivitasnya di berbagai organ. Penyinaran menyebabkan peningkatan aktivitas enzim secara terpadu yang mengubah fenilalanin menjadi p-kumail koeñim A, yaitu prazat bagi cincin-B flavonoid. Selanjutnya terjadi peningkatan aktivitas khalkon sintase dan akhirnya terjadi peningkatan jumlah flavonoid (Salisbury dan Ross, 1992).

Data-data yang diperoleh kemudian dianalisis statistik. Hasil uji Kolmogorof-Smirnov menunjukkan sampel terdistribusi normal dengan 
nilai signifikasi 0,299 >0,05. Kemudian dilakukan uji levene dan diperoleh nilai signifikansi $0,077>$ 0,05 , berdasarkan hal tersebut dapat diambil kesimpulan bahwa data homogen. Selanjutnya dilakukan uji parametrik ANOVA, yang hasilnya menunjukkan adanya perbedaan kadar flavonoid total yang signifikan antar kelompok dengan signifikansi $0,000<0,005$.

Dari uraian tersebut dapat dimengerti bahwa daun kepel yang tua lebih banyak mengandung flavonoid jenis flavonol atau flavon dibanding daun kepel yang masih muda. sementara pada biji buah diduga mengandung isoflavon tanpa 5-OH bebas yang berbeda dengan flavonol ataupun flavon. Biji memiliki tiga tempat penyimpanan zat aktif, diantaranya pada biji tersimpan di bagian sitoplasma yang banyak mengandung air, sehingga pada biji lebih sedikit kadar flavonoidnya dibanding pada daun.

Kadar flavonoid total pada ekstrak etanol daun kepel yang masih muda, yang tua dan biji buah berturut-turut adalah sebesar $(3,32 \pm 0,12)$; $(4,82 \pm 0,08)$, dan $(0,25 \pm 0,01) \% \mathrm{~b} / \mathrm{b}$.

\section{KESIMPULAN}

Berdasarkan hasil penelitian yang telah dilakukan dapat diambil kesimpulan bahwa kadara flavonoid total pada ekstrak etanol daun kepel yang muda, yang tua, dan biji buah kepel berturutturut adalah $(3,32 \pm 0,12) ; \quad(4,82 \pm 0,08)$, dan $(0,25 \pm 0,01) \% \mathrm{~b} / \mathrm{b}$. Kadar flavonoid total tertinggi terdapat pada ekstrak daun kepel yang tua yaitu $(4,82 \pm 0,08) \% \mathrm{~b} / \mathrm{b}$.

\section{DAFTAR PUSTAKA}

Anonim, 1986, Sediaan Galenik, 1-26, 4-10, 11-12, 56-57, Departemen Kesehatan Indonesia, Jakarta.
Anonim, 2009, Monograph Quercetin, Alternative Medicine Review Vol 3, Number 3, 1998, hal 140, Thorne Research.

Dalimartha, S., 1992, Tanaman Berkhasiat Obat Indonesia, Jilid I, 9, Pustaka Kartini, Jakarta.

Harborne, J. B., 1987, Metode Fitokimia Penuntun Cara Modern Menganalisis Tumbuban, Edisi II, diterjemahkan oleh Kosasih Padmawinata dan Iwang Soedira, 5, 69-76, ITB Press, Bandung.

Rinawati, T., 2004, Isolasi dan Karakterisasi Senyawa Golongan Alkaloid Daging Buah Burahol, Skripsi, Fakultas Farmasi Universitas Padjajaran, Bandung.

Salisbury, B, F. dan Ross, W, C., 1992, Plant Physiologi, $4^{\text {th }}$ edition. Wadsworth Publishing Co., A division of wadsworth, Inc, diterjemahkan oleh Dian R Lukman dan Sumaryono, Jilid III, 157-159, ITB, Bandung.

Siswono, 2002, Kepel, Deodoran Sekaligus Penyembuh Asam Urat, http://www.gizi.net/cgibin/berita/fullnews .coi?newsid1024300348,60462.

Soobrattee, A, M., Neergheen, S, V., Bahorun, T., and Aruoma, I, O., 2006, Characterization of The Phenolic Constituen in Mauritian Endemic Plants as Determination of Their Antioxidant Activities in Vitro, Journal of Plant Physiology.163 (2006) 787-799.

Sunarni, T., Pramono, S., dan Asmah, Ratna., 2007, Flavonoid Antioksidan Penangkap Radikal dari Daun Kepel (Stelechocarpus burabol Bl. Hook F. \& Th), Tesis, Fakultas Farmasi Universitas Gajah Mada, Yogyakarta. 